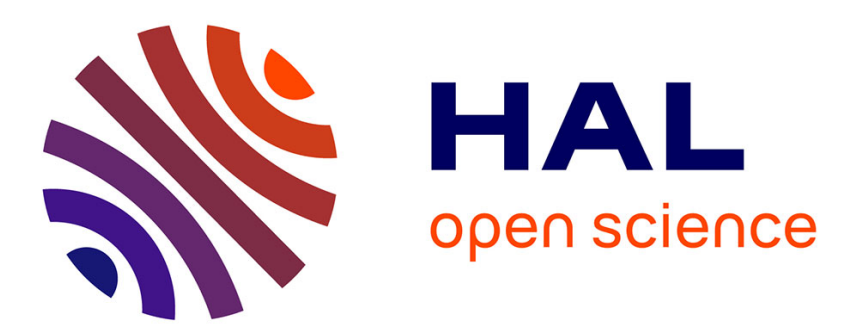

\title{
Access to Medicines in Developing Countries: Ethical Demands and Moral Economy
}

\author{
Maurice Cassier, Marilena Correa
}

\section{To cite this version:}

Maurice Cassier, Marilena Correa. Access to Medicines in Developing Countries: Ethical Demands and Moral Economy. Developing World Bioethics, 2014, 14 (2), pp.ii - viii. 10.1111/dewb.12066 . halshs-01894143

\section{HAL Id: halshs-01894143 \\ https://shs.hal.science/halshs-01894143}

Submitted on 23 Dec 2018

HAL is a multi-disciplinary open access archive for the deposit and dissemination of scientific research documents, whether they are published or not. The documents may come from teaching and research institutions in France or abroad, or from public or private research centers.
L'archive ouverte pluridisciplinaire HAL, est destinée au dépôt et à la diffusion de documents scientifiques de niveau recherche, publiés ou non, émanant des établissements d'enseignement et de recherche français ou étrangers, des laboratoires publics ou privés. 


\section{ACCESS TO MEDICINES IN DEVELOPING COUNTRIES: ETHICAL DEMANDS AND MORAL ECONOMY}

Maurice Cassier, CNRS, Paris, Marilena Correa, UERJ, Rio de Janeiro

Demands for access to pharmaceutical treatment have proliferated worldwide as a result of the HIV/Aids epidemic. In the late 1990s, the slogan of the South African organization Treatment Access Campaign in their street demonstrations was "Patients' Rights against Patent Rights". In 2006, Thai Aids patient organizations demanded the "right to life" as a justification for a "compulsory licence" decree allowing the production of generic medicines by copying patents without the patent-owner's authorization ${ }^{1}$. The Brazilian HIV/Aids patient organization ABIA decided in the same year to legally oppose a patent on the antiretroviral Tenofovir, frequently used in tri therapies, which was owned by Gilead. This opposition was filed in collaboration with the Indian HIV/Aids patient organization SAHARA. Their aim was to have Tenofovir put into the public domain, both in India and in Brazil. The arguments of these social movements that emerged in the context of the Aids epidemic and the arrival of highly sophisticated and expensive therapies had strong moral underpinnings: the right to life and the right to health, meaning social and global justice to access treatment that had until then been inaccessible to the world's poorest countries and people who had no social health insurance or other forms of mutual benefits. The demand for global justice underlay Act Up's calls for "Access for all" at the 1996 Montreal Aids congress. The accumulation of profits from vital goods was also condemned. In 1989, Act Up New York

\footnotetext{
${ }^{1}$ G. Krikorian, 2009, "The politics of patents: conditions of implementation of public health policy in Thailand" in S. Haunss and K.C. Shadlen (Eds), The Politics of Intellectual Property: Contestation over the Ownership, Use, and Control of Knowledge and Information (Edward Elgar, UK), pp. 29-55.
} 
attempted to disrupt Wall Street when Glaxo Wellcome's shares skyrocketed following the publication of positive clinical results for AZT.

One of our hypotheses concerns the sudden appearance of these demands for access to medicines in the fields of political activism and the pharmaceutical economy, from the late 1990s. We posit that the arrival of new antiretroviral technologies was concomitant with the emergence of an ethic of universal access to treatment, conveyed by non-governmental organizations and by the health policies of certain countries of the global South, such as Brazil, Thailand and Botswana, which we analyze in this issue of Developing World Bioethics. In a lecture in 1974 at the Rio de Janeiro Institute for Social Medicine, Michel Foucault pointed out the concomitance between the spread of antibiotics and the creation of health insurance in the $1940 \mathrm{~s}^{2}$. The clash between these ethical demands and intellectual property was particularly strong in the late 1990s, when the World Trade Organization extended medicine patents to all developing countries that until then did not have them. Brazil and India, which were producing affordable generic medicines for the populations of developing countries, were strongly affected.

The social movements that were active in the field of medicines, where they explicitly demanded "the right to life" or "patient rights" as opposed to exclusive property rights or industrial monopoly (e.g. the Thai HIV/Aids organizations studied here by Stéphanie Rosenberg), corresponded to a biopolitics that was produced, promoted and supported by the individual and collective subjects who were gaining access to a new form of citizenship qualified as therapeutic citizenship or bio-citizenship by some authors (Nguyen, 2002, Biehl, 2009) $)^{3}$. This ethic of access to treatment was part of a demand for

\footnotetext{
${ }^{2}$ Michel Foucault, "The Crisis of Medicine or the Crisis of Antimedicine?", 1st lecture on the history of medicine, Institute of Social Medicine, Rio de Janeiro, October 1974, Foucault Studies, No. 1, pp. 5-19, December 2004.

${ }^{3}$ Vinh-Kim Nguyen, 2002, "Sida, ONG et la politique du témoignage en Afrique de l'Ouest" Anthropologie et Sociétés, vol 26, no. 1, pp 69-87; Joao Biehl, 2009, "Accès aux traitements
} 
"power over life", to maintain, safeguard and protect it, in the same spirit as Michel Foucault's hypothesis in "The Will to Knowledge" ("Right of Death and Power over Life") ${ }^{4}$. Foucault pointed out that "it was life more than the law that became the issue of political struggles, even if the latter were formulated through affirmations concerning rights". "The right to life" and "the right to health", demanded by patient organizations and by Médecins sans Frontières' Campaign for Access to Essential Medicines, participated in these "demands for rights". Ethics was thus a strategic weapon used by patients and populations to stand up to the proprietary pharmaceutical economy, if not to force it to change. Foucault identified the emerging power of this "international citizenship" based on human rights, notably in the field of disease and health: "Amnesty International, Terre des Hommes and Médecins du Monde are initiatives that have created this new right - that of the private individual to effectively intervene in the sphere of international policy and strategy" ("Confronting Governments: Human Rights", in J. Faubion, ed., Power, 2000), pp. 474-475). The research published in this issue documents the actions of these civil society organizations in the field of government health policy during the negotiations of international organizations - the WHO and the WTO -, and on the economic strategies of pharmaceutical laboratories.

In this issue we see that the actions of patient organizations and international NGOs such as MSF and Oxfam occupied both the public sphere and the legal sphere. Ethical demands resulted in learning about intellectual property rights and more generally economic rights, so as not to leave the field open to the experts of legal consulting firms or of the large pharmaceutical companies. Patient organizations in Brazil, India and Thailand created groups of experts on intellectual property to launch campaigns for compulsory licences or

du sida, marchés des médicaments et citoyenneté dans le Brésil d'aujourd'hui", Sciences Sociales et santé, vol. 27, pp. 13-46.

${ }^{4}$ Michel Foucault, The History of Sexuality: the Will to Knowledge, Volume 1, Penguin, 1998. 
to draft opposition documents addressed to the national industrial property institutes, demanding the invalidation of certain patents.

The shift of humanitarian medicine towards global therapeutic activism aimed at equal access to treatment has been analyzed by Peter Redfield in the case of $\mathrm{MSF}^{5}$. The NGO first advocated access to medicines as part of its humanitarian action when emergency medicine was confronted with the unavailability of treatments, either due to their cost or because manufacturers had given up producing them or doing research on the disease ${ }^{6}$. Humanitarian medicine highlighted the loss of efficacy of certain medicines which had not been replaced by new therapeutic solutions, due to pharmaceutical laboratories' lack of investment in R\&D on tropical diseases. A "medicines unit" was created at MSF France in 1997 and a research group on "essential medicines" was set up. MSF adopted a strategy of publication in international medical journals to build the "neglected diseases" field and to remobilize the "essential medicines" field invented by the WHO in the $1970 \mathrm{~s}^{7}$. In the late 1990 s and early $2000 \mathrm{~s}$, the medical NGO created new organizations devoted to access to medicines: the Campaign for Access to Essential Medicines, known as the CAME, was founded in 1999, followed by the Drugs and Neglected Disease Initiative (DNDI), in 2003. The CAME was active in the field of law and the pharmaceutical economy, where it advocated for less stringent intellectual property rights so that treatments could be more readily available. It also produced a guide for purchasing antiretrovirals, designed especially for developing countries. The guide listed generics producers who could supply

\footnotetext{
${ }^{5}$ P. Redfield, "Doctors Without Borders and the Moral Economy of Pharmaceuticals" in Human Rights in Crisis, Edited by Alice Bullard, Ashgate 2008, p. 129-144.

${ }^{6}$ Bradol J.H., Vidal C., 2010, Innovations médicales en situations humanitaires. Le travail de Médecins sans Frontières, L'Harmattan, Paris.

${ }^{7}$ Jeremy Greene has pointed out that MSF became a mouthpiece for the "essential medicines" concept in the 2000s. "In distinguishing the ideal (essential drugs concept) from the real (WHO Model List of Essential Drugs List), MSF presented itself - a transnational NGO engaged in the process of getting drugs into bodies - as the new torch-bearer of the philosophy of essential medicines", in Making Medicines Essential: The Emergent Centrality of Pharmaceuticals in Global Health, BioSocieties Vol. 6, 1, 10-33, 2011.
} 
national and international medicines distribution programmes. MSF also published a guide on intellectual property rights (Drug Patent Report, 2003), for governments and civil society in developing countries. It was drafted by experts from the Oswaldo Cruz Foundation (Brazil), the DNDI, the Consumer Project on Technology in the USA, and the WHO. By creating the DNDI, MSF was moving into a new mode of intervention, that of pharmaceutical $R \& D$, to invent new therapeutic solutions accessible to the poorest populations. The NGO continued to collaborate with the federal laboratory in Rio de Janeiro to support the development of fixed-dose generic combinations or paediatric formulations that had been unavailable until then. In 2002 it set up a pilot operation distributing Brazilian generics in a South African clinic, in collaboration with the local Treatment Action Campaign (TAC). MSF was thus active in various areas of the medicines economy: the regulation of intellectual property rights; the demand for new patented therapies to be included in the WHO's list of essential medicines; pharmaceutical $R \& D$ for neglected diseases; and the direct distribution of medicines. In so doing, it combined the moral economy, political economy and industrial economy of medicines, with a view to making them a "public good" accessible to everyone.

While the collective actions of patient organizations and international NGOs played an essential part in building this new biopolitical field, the legal actions of patients or their families also participated in asserting demands for the "right to health" and the "right to life", to invent solutions for access to medicines. Work carried out by jurists and anthropologists in the Brazilian context enable us to analyze several rationalities in these legal actions. M. Ventura (2003), a lawyer working for HIV/Aids patient organizations, has shown jurists' work to assist patients who have instituted legal proceedings to obtain access to new antiretroviral therapies. These legal actions, initiated in the early 1990s, contributed to incorporating the right to health in jurisprudence and in the actual therapeutic care for patients. They precipitated the introduction of 
public programmes to distribute ARVs in the streets of Sao Paulo and Rio de Janeiro, followed by the federal law on free and universal access to ARVs, passed in 1996: "Legal actions constituted considerable jurisprudence that established the State's obligation to offer integral, free and universal treatment to carriers of the HIV virus" ${ }^{8}$. M. Ventura referred to "a strategic use of the law" by patients and the organizations defending them, and to "a legal guerrilla for new rights" in the context of the democratization of Brazil. These lawyers organized seminars to make their arguments on the right to health known in legal circles. Under the impetus of several patient organizations in Sao Paulo and Rio de Janeiro (GAPA, Grupo Pela Vidda) ${ }^{9}$, this legal action model spread to other States of Brazil. During this movement, legal actions were embedded in political campaigns to influence and define national health policy. In 1996 patient organizations were rallied to participate in the implementation of the national HIV/Aids programme, as experts.

Surveys undertaken a decade later by anthropologists J. Biehl and A. Petryna $^{10}$ in the State of Rio Grande Do Sul show the steep increase in legal actions by poor people, often retired or unemployed, to obtain access to medicines for chronic or rare diseases. These actions were attempts to compensate for the shortcomings and inadequacies of the public medicine distribution programmes. They were based on the right to health enshrined in the Constitution, and relied on the legal assistance provided by the State. The judges' decisions, which were mostly in favour of the plaintiff, were grounded on "the constitutional right to health" and the "constitutional right to life". While

\footnotetext{
${ }^{8}$ M. Ventura, 2003, "Strategies to promote and guarantee the rights of people living with HIV/AIDS", in Divulgaçao em saude para Debate, Rio de Janiero, no. 27, August 2003, pp. 239-251.

${ }^{9}$ GAPA: Aids Support and Prevention Group; Grupo Pela Vidda: Group for the Valorization, Integration and Dignity of the Aids Patient.

${ }^{10}$ Biehl J., Amon J.J., Socal P.P. and Petryna A., "Between the Court and the Clinic: Lawsuits fo medicines and the rights to health in Brazil", Health and Human Rights, vol. 14, no. 1, June 2012, pp. 36-52; Biehl J. and Petryna A., "Bodies of Rights and Therapeutic Markets", Social Research, vol.78, no. 2, summer 2011, pp.359-394.
} 
Miriam Ventura has shown a legal and therapeutic activism tending towards the adoption of public health policies, Biehl and Petryna have underscored the fragility of these multiple legal actions by "patients citizens consumers" taking place in the gaps in public policy and in a fast-growing medicines market.

The ethics of access to medicines was not only used by patients, whether individually or collectively. It was also conveyed by the pastoral State (Foucault) ${ }^{11}$ to protect its populations, by instituting forms of distributive justice and social security ("social property", defined by sociologist Robert Castel, to complete or make up for the flaws of private property) $)^{12}$. "Claims to rights" tended to be translated into laws following social protests or court cases. The demands of Brazilian sanitarist doctors in the 1970s and '80s resulted in the "right to health" being enshrined in the new Brazilian Constitution of 1988 (Loyola, 2009) $^{13}$. This right served as a lever for new social and legal struggles in the HIV/Aids era. A Brazilian law in November 1996 provided for free universal access to treatment for HIV/Aids patients. In this issue, Fanny Chabrol analyses the convergence between the ethics of the State's pastoral power in Botswana, and the ethics of private philanthropy conveyed by a global health partnership between the Bill Gates Foundation and the pharmaceutical laboratory Merck, to supply a national programme of free distribution of ARVs. The ethics of access to medicines has several sources: the "right to health" promoted by the pastoral State; the "right to live" demanded by patient organizations; and private philanthropy that initiated global health partnerships. For pharmaceutical laboratories, it was also a matter of restoring the moral credit they had lost during the case they had made against the South African

\footnotetext{
${ }^{11}$ Michel Foucault, 2009, Security, Territory, Population: Lectures at the Collège de France, Palgrave Macmillan.

${ }^{12}$ Propriété privée, propriété sociale, propriété de soi, Robert Castel and Claudine Haroche, Fayard 2001.

${ }^{13}$ Loyola MA. (2009) "Sida, santé publique et politique du médicament au Brésil : autonomie ou dépendance ?” Sciences Sociales et santé, 3, 27, pp. 47-75.
} 
Medicine Act in 1998 (the international coalition of pharmaceutical laboratories finally withdrew charges in 2001, due to the extent of international public mobilization). In the early 2000s, the Brazilian federal pharmaceutical laboratory offered to transfer its technologies to African countries that wished to set up their own generic medicine production laboratories. In November 2003, the President of Brazil announced the construction of a pharmaceutical factory in Mozambique, to produce ARVs in the country ${ }^{14}$.

The invention of an ethics of access to medicines was globalized to a very large degree. One of the most noteworthy events of this emergence was in November 2001 during the negotiations of the World Trade Organization in Doha. The ethics of the right to health was thus consecrated in the areas of international trade regulation ${ }^{15}$. The Doha Declaration established the priority of the right to health over property rights. This meant that States were justified in cancelling exclusive patent rights on medicines to protect their populations. As the right to health suddenly emerged in trade negotiations, the WHO set up task forces on "intellectual property, innovation and public health", and published guidelines to help developing countries to introduce flexibilities in their patent laws, to protect public health (Carlos Correa, 2007) ${ }^{16}$. In this issue of DWB, German Velasquez, an economist and expert in intellectual property at the WHO, meticulously reports on the discussions of a group of experts commissioned by the General Assembly for Health, which examined the introduction of the right to health into the economy of pharmaceutical innovation. International NGOs such as MSF and DNDI were instrumental in producing and spreading this ethic of "the right to health" and "the right to life", and ensuring that it was incorporated into health policies. The CAME

\footnotetext{
${ }^{14}$ Production was not launched until the end of 2013, primarily due to a particularly difficult technology transfer process.

${ }^{15}$ See Holger Hestermeyer, Human Rights and the WTO. The Case of Patents and Access to Medicines, Oxford University Press, 2007.

${ }^{16}$ Carlos Correa, 2007, Guidelines for the Examination of Pharmaceutical Patents:

Developing a Public Health Perspective, ICTSD, WHO, UNCTAD, Geneva.
} 
(Campaign for Access to Essential Medicines), initiated by MSF, was established in developing countries seen to be strategic (Brazil, South Africa, Thailand, India). NGOs organized world forums to promote access to medicines. We witnessed a global circulation of legal arguments within networks of patient organizations, as well as joint legal actions by several NGOs. Seminars in Rio de Janeiro brought together Brazilian and Indian jurists to work out opposition strategies to medicine patents. South-South circulation was superposed over North-South circulation via the legal assistance of certain foundations such as James Love's CPTech or organizations like Act Up. Global experts such as Carlos Correa, an Argentine academic jurist, assisted developing countries in strengthening their legal instruments to balance intellectual property and public health interests. They facilitated educational seminars on intellectual property in various regions of the world.

While we are intent on following the geographic circulation of ethical arguments for access to medicines, we also need to endeavour to produce a history of norm changes in this respect. In the late 1990s and the very early 2000s, as calls for access to antiretrovirals in developing countries intensified, World Bank experts deemed this policy to be "inequitable": "The use of public funds to subsidise the treatment of patients in the poorest countries who are most able to comply - who are better educated and have access to better health care would be highly inequitable and would shift health resources from the poor to those who are not poor" (Ainsworth and Teokul, The Lancet, 2000, vol. 356, July 1). This change of norms was described by an MSF doctor, Pierre Chirac, who highlighted the ethical resistance to policies of universal access, by many experts who thought that "we don't treat anyone if we don't treat everyone" and that access to ARVs for HIV/Aids was "unfair with regard to other diseases"17. It was the results of the Brazilian policy of universal and free distribution of

\footnotetext{
${ }^{17}$ Pierre Chirac, "Traitements ARVs dans les PED : historique et état des lieux", IMEA, 23 November 2010.
} 
ARVs that precipitated the change of health policy norms in this field. In fact, in 2003 the WHO appealed to the heads of the Brazilian programme to set up a world-wide system for the supply of HIV/Aids medicines and diagnostic tests in developing countries.

The process of change of ethical norms took various routes and forms, consisting essentially in: a) "demands for rights" formulated in public petitions, street demonstrations, public campaigns by patient organizations to demand the application of compulsory licences or the implementation of national or global programmes for access to treatment; b) legal actions were taken by individuals or by patients associations to demand the application of the "right to health" enshrined in the Constitution ; c) ethical norms on access to treatment were codified in laws (the Brazilian law of 1996 on universal access to treatment for HIV/Aids) and incorporated into public health policies and measures ; d) opposition proceedings under the patent law and before the patent office that allow third parties - as patients associations or Ministry of health- to require the invalidation of patents and to have therapeutic inventions put into the public domain (see the articles of Juliana Veras and Stéphanie Rosenberg in this issue, on the case of Brazil). The ethical demands conveyed by social movements or by legal actions have the effect of mobilizing the law and "creating" it through jurisprudence : “...within this context - the consolidation of brazilian democracy- it becomes very important to use law on behalf of public interest and to adopt litigation strategies used by the movement of people with Aids..." ${ }^{18}$. The lawyer Miriam Ventura has shown the inventive work of jurists who advised patient organizations in drawing up new interpretations of the right to health and the right to life. Federal judge Roger Raupp Rios, who analysed the legal responses to the Aids epidemic, spoke of "a fruitful dialogue that can

\footnotetext{
${ }^{18}$ Ventura M, Divulgaçao em saude para Debate, Rio de Janiero, no. 27, August 2003, p. 242.
} 
be established between law-making and jurisprudence, public policies, and initiatives by civil society, all in a virtuous circle"19.

Of note are the multiple feedback loops and interactions between ethics and law. At a conference on "medicines and the individual", jurists concluded that health law was opening to "...extra-judicial analyses drawing on economics, ethics or even social anthropology" (M. Bélanger) ${ }^{20}$. Several legal studies have highlighted the opening of international trade law to the right to health: "The decision of the TRIPS agreement in 2003 is certainly a major step forward as it is an international trade law text that is open to the protection of a non-market objective: the protection of health" (C. Jourdain-Fortier) ${ }^{21}$. In Human Rights and the $W T O^{22}$, Holger Hestermeyer analysed the conflicts and compromises between commercial law and human rights. He concluded the book with recommendations for more cooperation between the WTO and the WHO: "In the matter of TRIPS and access to medicines a WTO panel could seek information from the WHO or the Committee on Economic, Social and Cultural Rights on the effects of patents on public health or the right to health". He recommended the use of an article from WTO agreements on intellectual property providing for an exception for security reasons, which could include threats to human health. This would enable States facing public health crises to refuse patents on medicines to treat pandemics. It is important to note here that intellectual property law itself took the right to health into account by providing for measures to safeguard the population: "We agree that the TRIPS Agreement does not and should not prevent Members from taking measures to protect

\footnotetext{
19 "Legal Response to the HIV/Aids Epidemic in Brazil", Divulgaçao em saude para Debate, Rio de Janiero, no. 27, August 2003, pp. 228-238.

${ }^{20}$ Le médicament et la personne. Aspects de droit international, I. Moine-Dupuis (Ed.), Litec, 2007, Paris ; Clotilde Jourdain-Fortier, Santé et commerce international. Contribution à l'étude de la protection des valeurs non marchandes par le droit du commerce international, Travaux du Credimi, vol. 26, Paris, LexisNexis Litec, 2006, 699 pages.

${ }^{21}$ Le Médicament et la personne, Aspects de droit international. op. cit.

${ }^{22}$ Human Rights and the WTO, The case of Patents and Access to Medicines, Oxford University Press, 2007.
} 
public health. Accordingly, while reiterating our commitment to the TRIPS Agreement, we affirm that the Agreement can and should be interpreted and implemented in a manner supportive of WTO Members' right to protect public health and, in particular, to promote access to medicines for all" (Doha Declaration, WTO, 14 November 2001). The WTO Doha Declaration does in a sense make room for the pastoral State, protector of the population, as opposed to the State that guarantees the intellectual property of pharmaceutical inventions. To manage this tension, the DNDI Foundation proposed an approach combining the ethical principles of humanitarian medicine with pragmatism during the negotiations on IP rights on medicines that must be made accessible to those who need them the most: "The policy reflects the DNDI's philosophy, vision and mission ensuring that its products are accessible and affordable to patients who need them most. DNDI recognizes the reality of IP and seeks to implement its humanitarian mission using best, pragmatic practices for IP management" ${ }^{23}$.

The particularity of the point of view that we adopt here is that it focuses on and studies the process whereby human rights and ethics are put to work in "situated" actions, struggles and public policies, with regard to particular pathologies and therapies, in specific social histories and geographies. Peter Redfield (2008, op.cit.) refers to the combination of "Human Rights, Humanitarianism and the Practice of Virtue", to sum up the mobilization of human rights in the political practices and actions of humanitarian medicine. The articles in this issue enable us to map the actors of this ethics of the right to health and the right to universal access to treatment. This is a "civil society" composed of patient organizations and NGOs such as MSF and Oxfam, which conduct actions at local and international level. These organizations ally and collaborate on a long-term basis with certain developing countries, especially with national programmes for the distribution of medicines in the case of Brazil

\footnotetext{
${ }^{23}$ Pragmatic and Principled: DNDI's Approach to IP Management, DNDI, 2007.
} 
and Thailand. Ministries of Health can include public health doctors and patient organization activists to coordinate measures providing access to medicines. In Brazil and Thailand, public laboratories producing generics are also leading actors in these campaigns and actions. In India, the private laboratory Cipla is a promoter of access to medicines, if not an activist. International experts from academia, patient organizations (Act Up), medical NGOs (MSF), intergovernmental organizations (WHO), and foundations (the chemists of the Clinton Foundation who are helping Brazilian laboratories for the copying of tenofovir) work towards the creation of programmes for access to medicines or for the regulation of intellectual property to make it more favourable to public health. The main funders of global health are also involved, to support national programmes. Despite initial reticence to finance universal access to treatment, the World Bank has helped Brazilian NGOs who advocate free access to generics, and the Bill Gates foundation has funded a programme for the distribution of ARVs set up by the Botswana government in partnership with the pharmaceutical laboratory Merck. In all these situations, governments, and particularly Ministries of Health, appear to be obligatory points of passage for foundations, non-governmental organizations or patient organizations. The cooperation and tension between MSF and the Brazilian Ministry of Health were crucial in forcing the Brazilian government to decide on a compulsory licence on patented medicines, in initiating the development of new therapies for malaria or leishmaniasis, and in evaluating the technological capacities of Brazilian laboratories to duplicate complex medicines ${ }^{24}$. In the situations that we have studied, biomedical humanitarianism is allied with the authorities of developing countries to distribute treatment or to break down the barriers of

\footnotetext{
${ }^{24}$ In 2006, MSF and the Brazilian organization ABIA appealed to two internationally renowned chemists to assess the industrial capacities of Brazilian public and private laboratories. This expertise provided the Health Ministry with decisive information just when it was making a decision on a compulsory licence for Merck's Efavirenz: "ARV Production in Brazil. An Evaluation", J. Fortunak and O. Antunes, 2006.
} 
intellectual property. This seems to contradict the conclusions of Andrew Lakoff who insisted on a break between medical NGOs and State apparatus, probably with regard to the poorest countries, where the State is weaker than in Thailand or $\mathrm{Brazil}^{25}$.

We have explained the ethical demands for access to medicines in developing countries made through the mobilization of human rights, the right to health, and the right to life (Foucault), in order to influence intellectual property rights and health policies, and even to envision and implement new pharmaceutical economies (free distribution of medicines by the State, in Brazil and Thailand; or the therapeutic innovation systems studied by German Velasquez and Koichi Kameda in this issue). These demands and collective actions for access to treatment can also be justified by the notion of "moral economy" put forward by the English historian Edward Thompson in 1971, to explain the economic rationality of riots for a "fair price" of wheat and bread at the end of the $18^{\text {th }}$ century. At the time, the establishment of a capitalist market was overriding customary rights of access to bread for the poorest ${ }^{26}$. The advocacy of patient organizations and MSF for access to medicines and for measures to safeguard public health within IP law seems very similar to the rationality of the moral economy of popular protests for bread, analyzed by $\mathrm{E}$. Thompson ${ }^{27}$. This moral economy of medicines seems to underpin not only the ethical demands for access to treatment but also the pharmaceutical economies set up to distribute generic medicines or to develop new medicines against socalled neglected diseases, for example in the context of partnerships coordinated

\footnotetext{
${ }^{25}$ Andrew Lakoff, 2010, Two Models of Global Health, Humanity: an International Journal of Human Rights, Humanitarism and Development, Vol 1, no. 1, pp. 59-79.

${ }^{26}$ Edward Thompson, "The moral economy of the English crowd at the end of the eighteenth century", Past and Present, no. 50, pp. 76-136.

${ }^{27}$ Anthropologist P. Redfield has also shown the analogy between working-class protests in the 18th century against the price of wheat, and MSF's positions for equal access to medicines: "...the feeling in and beyond MSF that the availability of goods such as medicines should not be governed solely by motives of profit", in "Doctors Without Borders and the Moral Economy of Pharmaceuticals" in Human Rights in Crisis, Edited by Alice Bullard, Ashgate, 2008, pp. 129- 144.
} 
by the laboratory founded by MSF in 2003, the DNDI. Here ethics "informs" the real economy, in the sense of intervening to regulate intellectual property and the price of medicines (see the guidelines drawn up by the DNDI on the legal appropriation of medicines, which provide for either the non-patentability of inventions, or for the setting of royalty rates that are compatible with very low prices, and generally formulae of non-exclusive licences to facilitate the spread of the production of therapies ${ }^{28}$. It is also this ethics of equal access to treatment that inspired MSF's proposal to organize a community of patents on ARVs - a community that was hosted from July 2008 by UNITAIDS. However, the regulation of intellectual property by ethics has limits. Only the NIH and one pharmaceutical firm, Gilead, agreed to put their patents in this pool to be conceded to generics laboratories by way of non-exclusive licences. Gilead however drew up a list of beneficiary countries that excluded Brazil, where its patent on Tenofovir was contested by the federal pharmaceutical laboratory Farmanguinhos and by patient organizations.

Anthropological studies also show certain limits to the actions undertaken to secure access to treatment. Multiple individual legal actions for access to treatment are likely to create new inequalities in access to health (Biehl and Petryna, 2011, op.cit.). Lawyer Miriam Ventura has signalled the limits of legal actions focused on access to health, in a context of structural problems of access to employment ${ }^{29}$. J. Biehl (2009, op.cit.) has also pointed out, in community-run sites called houses of support - casa de apoio - of Bahia, the limits of the poorest patients' inclusion in HIV/Aids therapeutic care programmes, despite the efforts of the State and NGOs to assist. This has revealed the fragilities of the acquisition of "therapeutic citizenship" in view of vertiginous social inequalities.

\footnotetext{
${ }^{28}$ Banerji J. and Pecoul P., "Pragmatic and Principled: DNDi’s approach to IP management" in Intellectual Property Management in Health and Agricultural Innovation: A Handbook of Best Practices A Krattiger, RT Mahoney, L Nelsen, et al. (Eds), MIHR: Oxford, U.K, 2007, p 1775-1782.

${ }^{29}$ M. Ventura, 2003, op.cit., p.246.
} 
In his work on Botswana, F. Chabrol revealed the process of selection of eligible sites to set up global health programmes - a process that closely intertwines management and philanthropy, to ensure a "promising" return on investments for the donation of medicines ${ }^{30}$. Uganda, which at one stage was selected by the United States to host an ARV distribution programme, turned out to be too highly populated and too difficult to supply with medicines, whereas Botswana has a small population ( 2.5 million inhabitants) and a highly active Ministry of Health. The latter country was therefore ultimately chosen.

The six articles in this special issue of DWB enable us to follow the emergence of this ethics of access to medicines from the late 1990s. By means of participant observation, two articles, those of Rachell Kindell Moore and of German Velasquez, study discussions and conflicts over access to medicines and intellectual property in the framework of international WHO negotiations at Doha in 2001, along with the work of the expert group appointed by the WHO in 2006. Four articles analyze in detail the ethical demands and mobilization of the right to health in several situations, as well as singular arrangements to organize access to treatment in Botswana, Brazil and Thailand, and in the framework of an international consortium to invent new medicines against malaria, the FACT (Fixed-Dose Artesunate Combination Therapy Project). Whereas we have situated the emergence of these ethical demands and aspirations within the context of the Aids epidemic and the arrival of antiretroviral tri-therapies in the late 1990s, the articles in this issue envisage other medical and social fields, particularly that of "neglected diseases". This concept was first put forward by MSF in international medical journals in the early $2000 \mathrm{~s}^{31}$ to mobilize various public institutions in the global South (the Oswaldo Cruz Foundation, the Indian Council of Medical Research, the Kenya

\footnotetext{
${ }^{30}$ F. Chabrol, "Prendre soin de sa population : Le Bostwana entre politiques globales du médicament et pratiques locales de citoyenneté", PhD thesis in sociology, EHESS, 2012.

${ }^{31}$ P Trouiller et al., "Drug Development for Neglected Diseases: A Deficient Market and a Public Health Policy Failure", The Lancet 359 (2002): p. 2188.
} 
Medical Research Institute, the Malaysian Ministry of Health), to develop new therapies that would be affordable for the poorest countries.

Rachell Kindell Moore's article, "Access to Medicine and Distributive Justice: Breaching Doha's Ethical Threshold", focuses on access to treatment for non-transmissible diseases whose impact is increasing strongly in developing countries. It analyzes the sudden emergence of the right to health in WTO negotiations at Doha in 2001, and its continuation up to the present. The author shows that the Doha Declaration of November 2001 on the TRIPS Agreement and Public Health established the priority of justice in global health, a priority which seems to have been challenged in more recent negotiations on nontransmissible diseases.

German Velasquez's article introduces us into international negotiations held from 2006 to 2008 in the framework of an expert group responsible for devising new solutions for diseases affecting developing countries, and for making the therapies more accessible. These negotiations focused sharply on the pre-eminence of the right to health over commercial interests, on the use of international law to reinforce the right to health, where necessary through an international convention under the auspices of the WHO, and on the design of new models for the economics of innovation, to cover the needs of so-called neglected diseases. A convention of this nature could set up a public research fund to produce therapeutic inventions, also put into the public domain. German Velasquez' participation in these negotiations, as a WHO expert, has enabled him to describe the way in which power relations played out between groups of countries, as well as the formation of coalitions, for example between African or Latin American countries in Rio, to promote new solutions.

The article by Fanny Chabrol sums up meticulous anthropological research carried out at the Gaborone hospital and the Ministry of Health in Botswana, and at the Harvard School of Public Health in the USA, to study the implementation of the programme for free access to ARVs in this southern 
African country. Botswana was chosen by Merck, the Gates Foundation and the US government once the local government was sufficiently equipped from a sanitary point of view to host and efficiently use the researchers, doctors and medicines from the US, and once the country was drawing sufficiently sure revenue from the mining economy to participate in supporting the programme. Fanny Chabrol analyses the blind spots that appeared in this programme of free access to ARVs when the Botswana government demanded that patients be screened for eligibility, according to their nationality.

Whereas Botswana is absent from the arguments of international therapeutic activism, Stéphanie Rosenberg's article provides a richly documented analysis of the collective actions of patient organizations and international NGOs for access to treatment in two countries, Brazil and Thailand, which are, on the contrary, at the heart of conflicts over the right to health and the right to intellectual property. Patients' power is allied in these two countries with the Ministries of Health and the public laboratories which produce ARVs to supply their national Aids programmes. The ethical argument is a strategic instrument of patients' struggles to remove the obstacle of medicine patents.

In her article Juliana Veras sheds light on the legal battles of patent organizations and the Ministry of Health in Brazil to demand the cancellation of patents, so that generic medicines can be produced locally. She examines the circulation of legal arguments between Brazil, India and the US, and reveals the mediation of MSF. The battle was not only legal, but also technological and industrial. Juliana Veras' article describes very clearly the new public/private partnerships set up by the Brazilian authorities to produce a molecule that is very difficult to reproduce, Tenofovir, with the help of chemists of the Clinton Foundation. She points out "the moral dimension" of pharmaceutical inventions, associated with their accessibility and availability for patients' needs. 
Koichi Kameda reports on a survey that he conducted on the international consortium set up in 2003 to develop new therapeutic combinations for malaria. This consortium inaugurated a new pharmaceutical innovation economy which prioritizes the sharing of knowledge, the production of medicines at very modest prices for patients in developing countries, and the non-patentability of treatment. The novelty of this system is that it brings together public and private organizations from the South and the North: several universities and hospitals from UK, France, Malaysia, Burkina Faso ; the Brazilian federal laboratory Farmanguinhos ; Aventis in France ; Cipla in India, under the governance of a non-profit organization, the DNDI. In other words, a form of moral economy in the field of medicines. 